\title{
Crisis Coordination \\ and Communication During the 2010 Eyjafjallajökull Eruption
}

\author{
Deanne K. Bird (0), Guðrún Jóhannesdóttir, \\ Víðir Reynisson, Sigrún Karlsdóttir, \\ Magnús T. Gudmundsson and Guðrún Gísladóttir
}

\begin{abstract}
Eyjafjallajökull became Iceland's most infamous volcano in 2010 when the ash cloud from its summit eruption caused unprecedented disruption to the international aviation industry and considerable challenges to local farming communities and villages. The summit eruption, which began on 14 April 2010, was preceded by a 24-day long effusive flank eruption that produced spectacular fire-fountain activity and lava flows. The 39-day long summit eruption, however, was far more explosive and resulted in medium-sized jökulhlaups to the north, small jökulhlaups and lahars to the south and considerable ash fall to the east and east-southeast of the volcano. As in other crises in Iceland, the Department of Civil Protection and Emergency Management (DCPEM) coordinated efforts and facilitated crisis communication, while collaborating with the Icelandic Meteorological Office, the Institute of Earth Sciences at the University of Iceland and the National Crisis Coordination Centre. The DCPEM's role included providing information to the government and its various agencies and feeding information from scientists to local police officials, civil protection committees and the public. Communication with local residents took place through agencies' websites, the national media and frequent open town hall meetings where representatives of institutions responsible for eruption
\end{abstract}

The original version of this chapter was revised: An affiliation has been updated. The erratum to this chapter is available at 10.1007/11157_2017_22.

D.K. Bird $(\bowtie) \cdot$ G. Gísladóttir

Institute of Life and Environmental Sciences, University of Iceland, Reykjavík, Iceland e-mail: deanne.bird@gmail.com

\section{G. Jóhannesdóttir}

Department of Civil Protection and Emergency Management, National Commissioner of the Icelandic Police, Reykjavík, Iceland

\section{Reynisson}

South Iceland Police, Reykjavík, Iceland

S. Karlsdóttir

Icelandic Meteorological Office, Reykjavík, Iceland

M.T. Gudmundsson · G. Gísladóttir

Nordvulk, Institute of Earth Sciences, University of Iceland, Reykjavík, Iceland 
monitoring, health, safety and livestock handling provided advice. These face-to-face meetings with local residents were critical as ash fall had not affected these areas for over 60 years and plans for dealing with this hazard were not established. This chapter explores these events and in doing so, provides a narrative of crisis coordination and communication in Iceland. The narrative is based on multiple sources, including an analysis of community perspectives of the emergency response and their use and views of the various forms of communication platforms. The chapter also considers the eruptions' impacts at the local level. This exploration reveals that the trust developed through close communication between all involved prior to and during the eruption increased the effectiveness of crisis communication. The experience gained from the Eyjafjallajökull eruption is important for volcanic crisis communication at a local and international level. While the immediate evacuation plans were effective, the ash fall problems illustrated the need for necessary precautions and broadly defined preparedness strategies.

\section{Introduction}

The Eyjafjallajökull volcano (Fig. 1), which is overlain by a $200 \mathrm{~m}$ thick ice-cap bearing the same name, has produced three eruptions since the tenth century: in 1612, from 1821 to 1823 , and the recent 2010 events. Past eruptions have produced very fined-grained ash deposits typically found within a $10 \mathrm{~km}$ radius from the Eyjafjallajökull crater (Larsen et al. 1999) and only small to medium $\left(3000-30,000 \mathrm{~m}^{3} \mathrm{~s}^{-1}\right)$ glacial outburst floods (jökulhlaups) (Guðmundsson et al. 2005).

Initial volcanic risk management plans, developed from as early as 1973 for southern Iceland, did not include response to an Eyjafjallajökull eruption. These plans have, however, undergone revisions since 2002 to rectify this omission due to the realised threat evidenced by continuing magma intrusions in Eyjafjallajökull. The most dangerous aspect of a sub-glacial eruption, based on historic eruptions not least from Katla the volcano underlying Mýrdalsjökull glacier, are jökulhlaups, i.e. massive glacial outburst floods carrying volcanic debris and ice as sub-glacial eruptions melt through the glacier ice. Efforts made in 2003-2006 were therefore aimed at understanding and mitigating the risk from eruptions in both Mýrdalsjökull (Katla) and Eyjafjallajökull, in relation to reducing the likelihood of accidents and fatalities to jökulhlaups (Guðmundsson and Gylfason 2005). A high degree of volcanic risk awareness leading up to the 2010 eruption and the semi-established communication lines between key stakeholders were partly the outcome of this work.

As the work, however, had focussed on this most dangerous and life-threatening aspect, relatively little attention had been paid to the societal and health effects of weeks of repeated ash fallout on people and the agricultural industry, which is a critical component of the region's economy (Bird and Gísladóttir 2012). Moreover, as the plans were aimed at mitigating jökulhlaup risk, they were developed for a local response only; they did not consider international impacts of an ongoing eruption or a response to deal with the overwhelming international interest in the event (Heiðarsson et al. 2014).

Understandably, local agencies faced significant challenges responding to the 2010 eruptions. Hence, the purpose of this chapter is to provide a narrative of crisis coordination and communication in Iceland through the lens of the 


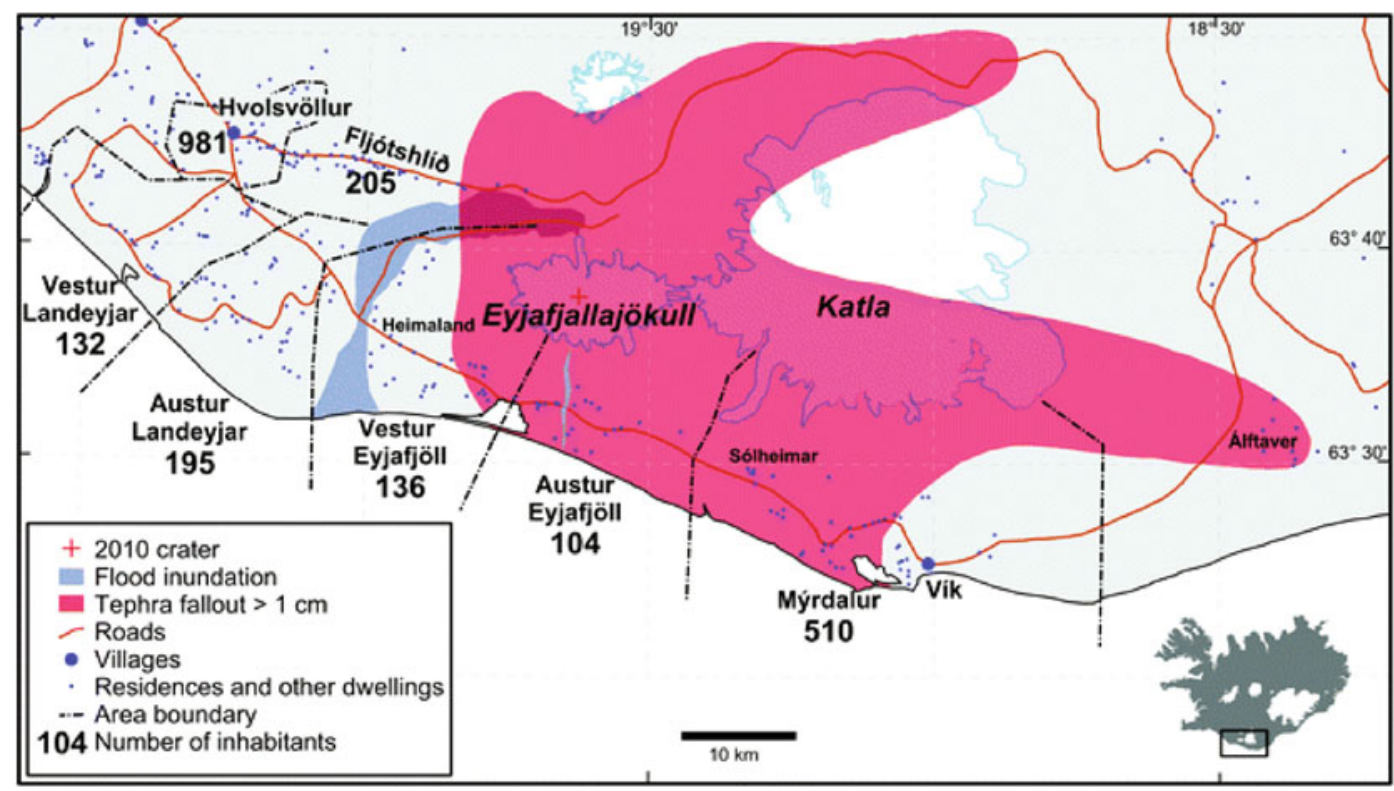

Fig. 1 Eyjafjallajökull, Katla and the surrounding districts. The areas impacted by jökulhlaup (flood) inundation and where cumulated ash fall exceeded $1 \mathrm{~cm}$, are shown. Tephra fallout and flood inundation data derived

Eyjafjallajökull eruptions. This narrative is developed using multiple sources, including an analysis of community perspectives of the emergency response and their use and views of the various forms of crisis communication. The chapter also considers the eruptions' impacts at the local level.

To provide context, the chapter first describes the roles and responsibilities of local, key agencies involved in civil protection and emergency management in Iceland. This is followed by a description of contributing resources and data collection methods used in this chapter.

\section{Civil Protection and Emergency Management in Iceland}

The Minister of the Interior is head of civil protection and emergency management in Iceland with the National Commissioner of Police (NCIP) responsible for all issues at the national level (Fig. 2). Sitting within the NCIP is the Department of Civil Protection and Emergency from Gudmundsson et al. (2012) and Porkelsson (2012). Population data was sourced from Ísólfur Gylfi Pálmason, the head of the Rangárping eystra municipality, and Statistics Iceland (2016)

Management (DCPEM), which is responsible for all daily matters including crisis communication, emergency coordination efforts and disaster recovery in relation to all hazards affecting the nation (Almannavarnir 2016a). At the local level, Chiefs of Police (Municipal Authorities) and Civil Protection Committees are responsible for civil protection activities and emergency response plans within their jurisdictions (Johannesdottir 2016).

Representatives from all these levels form the Civil Protection and Security Council, which sets strategies relating to civil protection, security and emergency management for the nation for 3 -years at a time. This includes developing and implementing strategies to prevent and/or mitigate physical injury, impacts on public health and damage to the environment and property, in addition to providing emergency relief and assistance (Johannesdottir 2016).

The Civil Protection Act No. 82, 2008 states that NCIP is responsible for assigning alert levels (Text box 1), in collaboration with the relevant Chief of Police, for all natural and man-made 
hazards (Ministry of the Interior 2008). Based on their real-time hydrological, meteorological and seismological assessments, notifications of an impending eruption usually come from the Icelandic Meteorological Office (IMO). In this instance, DCPEM call a meeting with experts, such as those from IMO and the Institute of Earth Sciences (IES) at the University of Iceland, to evaluate the risk and make recommendations with respect to the alert levels.

\section{Text Box 1: Alert Level Phases, as Assigned by the National Commis- sioner of the Icelandic Police (Alman- navarnir 2016b)}

\section{Uncertainty Phase (Óvissustig):}

Uncertainty phase/level is characterized by an event which has already started and could lead to a threat to people, communities or the environment. At this stage the collaboration and coordination between the Civil Protection Authorities and stakeholders begins. Monitoring, assessment, research and evaluation of the situation is increased. The event is defined and a hazard assessment is conducted regularly.

\section{Alert Phase (Hættustig):}

If a hazard assessment indicates increased threat, immediate measures must be taken to ensure the safety and security of those who are exposed/in the area. This is done by increasing preparedness of the emergency- and security services in the area and by taking preventive measures, such as restrictions, closures, evacuations and relocation of inhabitants. This level is also characterized by public information, advice and warning messages.

\section{Emergency Phase (Neyðarstig):}

Emergency phase is characterized by an event which has already begun and could lead, or already has led to, harm to people, communities, properties or the environment. At this stage, immediate measures are taken to ensure security, save lives and prevent casualties, damage and or loss.
In addition to their advisory role with DCPEM, IMO is tasked with monitoring, forecasting and disseminating natural hazard warnings to aviation service providers and the public (Karlsdóttir et al. 2010; Vogfjörd et al. 2005). During the Eyjafjallajökull eruption: hydrological sensors were used to monitor river runoff in terms of chemical composition and jökulhlaup risk; meteorological sensors and visual observations were used to assess lightning hazards, behaviour of the eruption cloud and localised ash fall; and, seismic, strain and GPS sensors were used to assess the geophysical components (Gudmundsson et al. 2010; Karlsdóttir et al. 2010).

The main role of IES is research in earth sciences, including a strong emphasis on volcanology. The institute undertakes core research in volcanic activity as well as the associated hazards and environmental impacts. While IES research includes monitoring via GPS measurements, INSAR, glacier surface surveying and seismic measurements, real-time monitoring remains the responsibility of IMO. As such, IES does not have any statutory obligations with respect to the monitoring and communication of volcanic activity. However, IES is called upon to provide advice to DCPEM and other government agencies prior to and during times of volcanic crises (Porkelsson 2012).

Also sitting under the NCIP and managed by DCPEM is the National Crisis Coordination Centre (NCCC), comprising staff from NCIP, Emergency Call Centre 112, Icelandic Coast Guard, Icelandic Red Cross, National Health Care System, rescue teams (ICE-SAR), ISAVIA (national airport and air navigation service provider of Iceland) and others (Heiðarsson et al. 2015). Based in Reykjavik, NCCC is responsible for coordinating a national response when the event affects several civil protection districts across the nation.

\section{Methods}

Multiple sources of data were used to develop this narrative of crisis coordination and communication during the 2010 Eyjafjallajökull 
Fig. 2 Iceland's current Civil Protection Structure, as of November 2016 (from Almannavarnir 2016a)

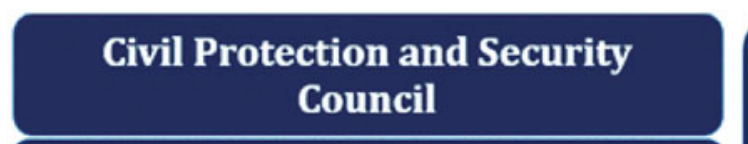

Minister of the Interior

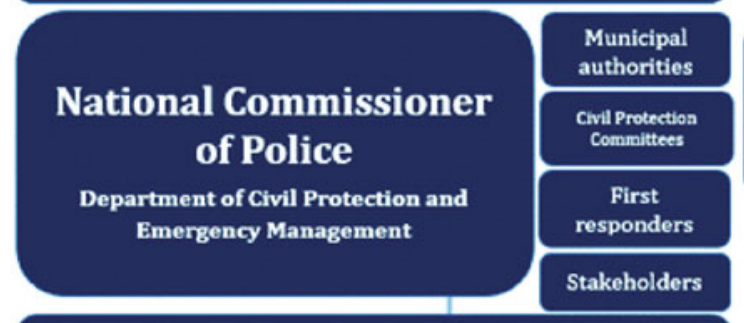

National Crisis Co-ordination Center

\section{Local Crisis Co-ordination Center}

\section{Temporary Service Center}

\section{Civil Protection Investigation Committee}

Preparation of the

Civil Protection

system

Monitoring,

analysis and

preparedness

Prevention and Mitipation

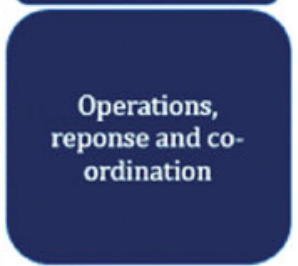

Rebuilding and recovery

Evaluation and lessons learnt eruptions. Firstly, published reports and academic articles were critically reviewed with reference to the events as they unfolded, with a particular focus on the activities, challenges and achievements of DCPEM, IMO and IES at the local level. Secondly, personal experience of the authors (Jóhannesdóttir, Reynisson, Karlsdóttir, Gudmundsson) who were heavily involved in response and recovery efforts through their positions within DCPEM, IMO and IES provided added detail to that generated from the published reports and academic articles. Thirdly, survey data collected by Gísladóttir and Bird in August 2010 was used to enhance understanding from a community perspective.

The survey incorporated 15 semi-structured interviews with officials and residents alongside a questionnaire disseminated to households living within the vicinity of the Eyjafjallajökull and
Katla volcanoes. Out of 61 households, 58 completed the survey giving a response rate of 95\%. This included 19 households from Vestur-Eyjafjöll, 26 from Austur-Eyjaföll, seven from Sólheimar and six from Álftaver (see Fig. 1), covering approximately 141 adults and 38 children. These communities were targeted due to their exposure to volcanic hazards (ash, debris-flows, jökulhlaup, lahars, etc.) during the 2010 eruptions. Every permanent household exposed to volcanic hazards during the 2010 Eyjafjallajökull eruptions was approached in these communities.

The questionnaire and semi-structured interviews asked respondents to detail their: personal experience prior to and during 20 March and 14 April eruptions; affects of the eruptions on individuals, family, property and businesses (agriculture/tourism); and, use of various media 
sources to access information on Eyjafjallajökull and Katla. Katla was included here as earlier response plans were centred on a Katla eruption rather than a response to an Eyjafjallajökull eruption.

It is beyond the scope of this chapter to present all survey data (some results have been presented by Bird et al. 2011, Bird and Gísladóttir 2012). However, some pertinent points are raised here as they directly relate to crisis coordination and communication during the 2010 events. These points, identified as 'survey' data, are interspersed throughout the following sections. All published reports and academic articles are cited accordingly.

Bringing these sources of information together, the following sections detail the events as they unfolded, with a particular focus on the activities, challenges and achievements of the key agencies and local residents' views of and responses to crisis coordination and communication.

\section{Crisis Coordination and Communication During the Eyjafjallajökull Eruptions}

\subsection{March 2010 Events}

In light of increased seismic rates in and around Eyjafjallajökull at the start of 2010 (Gudmundsson et al. 2010), the regional Chief of Police and the DCPEM organised emergency management meetings with scientists, local police and rescue teams. These meetings began in February 2010 and included 10 community meetings with residents living in the expected hazard zone around Eyjafjallajökull up to one week prior to 20 March 2010 flank eruption. Evacuation plans in case of jökulhlaup from an Eyjafjallajökull eruption were finalised during this period (Bird et al. 2011).

The initial stages of 20 March 2010 eruption were of very modest magnitude and despite comprehensive monitoring systems, it was first observed that evening by farmers who reported "a fire on top of the mountain" to local police (Bird et al. 2011). Hence, it is not surprising that the survey revealed the majority $(50 \%)$ of respondents heard about the commencement of the eruption via a family member, friend or neighbour. A further 17\% heard from DCPEM while $14 \%$ heard of the news over the radio.

As observer reports were received of the initial eruption on 20 March 2010, DCPEM and other authorities began rapid response efforts while IMO and IES scientists monitored real-time data to assess the situation (Porkelsson 2012). The pre-defined plans for evacuation, based on the hazard assessment from 2005 (see Guðmundsson and Gylfason 2005) were implemented for the first time in the early hours of 21 March. The first evacuation orders were disseminated via an automated phone alert system, supervised by the local Chief of Police (Gudmundsson et al. 2010). This was critical, given that a jökulhlaup from an Eyjafjallajökull eruption has the potential to impact inhabited areas within $1 \mathrm{~h}$ (Sigurðsson et al. 2011).

However, some survey respondents indicated that they did not receive the SMS or call to evacuate while others who did receive it chose to ignore it.

We did not evacuate our home, in these farms here, because there was no risk that the flood would reach the farms, but there was a possibility that we would be cut off. Everyone in this home was pleased with the decision, because it is better to be cut off being at home than to evacuate and unable to return home and attend the livestock.

...we did not receive any message, neither on the landline nor to the GSM phone. Everyone should have received a message that an eruption had started but we did not receive any for the Fimmvörðuháls eruption or the Eyjafjallajökull eruption.

Nevertheless, approximately 700 residents conformed during the early hours of 21 March and in general, survey respondents were more positive than negative about the coordination of the evacuation (Fig. 3).

The main criticism towards the coordination was in relation to lack of planning, with some residents stating that they were confused about who was to go where. 
Fig. 3 Respondents' feelings towards the management of 14th April the evacuations in relation to the 20 March and 14 April eruptions

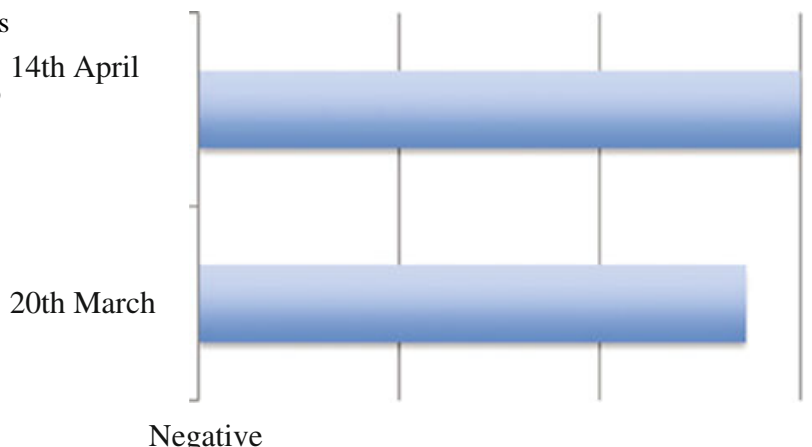

Negative
In our area the planning for the evacuation and the evacuation centre was not good, it should have been planned better.

As soon as the eruption site was located in the early morning on the flank of Eyjafjallajökull and not under the ice-cap, residents were allowed to return to their homes.

Although this eruption was relatively small, its impressiveness attracted thousands of onlookers that hiked the $16 \mathrm{~km}$ one-way trek with over $1000 \mathrm{~m}$ elevation to witness the eruption (borkelsson 2012). Continuing for 24 days, this 'tourist eruption' produced spectacular fire fountains and lava flows. As reported by survey interviewees and Porkelsson (2012), the main task of DCPEM, the police and rescue teams during this time was managing crowd control on site; a task that was made all the more difficult due to the extreme conditions and often very ill-prepared onlookers who lacked suitable clothing for the cold, were exhausted, and sometimes needed assistance with broken down vehicles. Tragically, two people lost their lives while trying to access a suitable viewing point from the north of Eyjafjallajökull. Although tragic, it is surprising that these were the only fatalities considering the adverse conditions and thousands of keen spectators trying to access the eruption site (Donovan and Oppenheimer 2010).

\subsection{April 2010 Events}

On 14 April 2010, after 1-2 days lull in activity, the explosive summit eruption began in the ice-filled caldera of Eyjafjallajökull (Porkelsson 2012), creating with it new vents under the ice-cap (Sigmundsson et al. 2010). Preparation done in the years prior to the eruption proved crucial to the execution of monitoring, in particular relating to the life-threatening flood hazard. Direct and rapid communication between monitoring scientists at IMO and IES with DCPEM and local police prompted response such as road closures and evacuations in line with the hazard assessment-based pre-defined plans.

Evacuation orders were again disseminated via the automated phone alert system with approximately 800 residents complying before daybreak on 14 April (Gudmundsson et al. 2010). The need for evacuating the region was realised with the impact of jökulhlaups charged with volcanic debris and icebergs, travelling at very high velocities $(<20 \mathrm{~km} / \mathrm{h}$ ) (Sigurðsson et al. 2011). These floods destroyed farmlands and caused some damage to roads and infrastructure but no lives were lost (Gislason et al. 2011).

In comparison to the 20 March eruption, the greatest proportion of survey respondents indicated they heard about the possibility of Eyjafjallajökull erupting for a second time from the Chief of Police/police (40\%) but received news of the start of the 14 April eruption over the radio (36\%). A further $21 \%$ stated they heard about the commencement of the eruption via a family member, friend or neighbour. Survey respondents were more positive about the coordination of the evacuations (see Fig. 3), stating that the 
planning was much improved from the 20 March eruption with better information.

The evacuation went better because of the experience from previous eruption.

You never know what will happen and it is good that people are together if something happens.

However, criticism still ensued in relation to the choice of evacuation centre for people living in Vestur-Eyjafjöll. Here, residents were required to evacuate to Heimaland, which is low-lying and considered to be vulnerable to jökulhlaup.

The planning was in general $\mathrm{OK}$ especially for Landeyjar. But the evacuation for Vestur-Eyjafjöll was not OK. It was a terrible mistake to evacuate to Heimaland, that place is not safe.

The potentially life threatening flood hazard subsided after 4-5 days. After that, the ash hazard and possible changes to the activity became more central to emergency response efforts. The eruption was producing very fine-grained ash ejected almost $10 \mathrm{~km}$ into the atmosphere (Gudmundsson et al. 2010) with extremely sharp and hard particles, justifying grave concerns for aircraft, as the ash had the ability to cause window and body abrasions as well as melt jet engines (Gislason et al. 2011). The summit eruption also produced lightning with a total of 790 strikes detected (Bennett et al. 2010), gas emissions, heavy sound blasts and lava flows reaching over $3 \mathrm{~km}$ down the slopes on the north side (Gudmundsson et al. 2012; Veðurstofa Íslands 2010). Linked to the thick ash layers deposited on the glacier and its foot hills, post-eruptive lahars and debris-flows repeatedly impacted rivers to the south of the crater (Jensen et al. 2013).

Already established communication links, which had been tested through regular exercises with London Volcanic Ash Advisory Centre (VAAC), ISAVIA, EUROCONTROL (European Organisation for the Safety of Air Navigation) and Toulouse VAAC, ensured IMO were better prepared to effectively communicate plume information to relevant international stakeholders. Nonetheless, improvements were made, including 3-hourly reports detailing plume activity for the use of international institutes and organisations and, joint daily reports from IMO and IES (Karlsdóttir et al. 2010; Porkelsson 2012), which served the use of DCPEM, the media and general public (see http://en.vedur.is/ earthquakes-and-volcanism/articles/nr/1884).

Other improvements included modifications to the IMO website, in order to enhance communication with the broader population. Launched on the second day of the summit eruption, additional pages containing relevant background and overview information were added to the website, alongside IMOs real-time monitoring data (Porkelsson 2012). These were done 'in order to achieve the goal of being more flexible and communicative to the public, so guaranteeing its considerable educational value and ensuring the public trust in the IMO services' (Heiðarsson et al. 2014, p. 62).

Similarly, IES developed a designated webpage for the Eyjafjallajökull eruption as part of their website (see http://earthice.hi.is/eruption_ eyjafjallajokull_2010). Here, the general public along with government officials and agencies were able to access timely data including status reports, satellite images and maps, GPS time series data, chemical composition analyses of rocks and ash, grain size distribution of ash, photos of the eruption, lahar reports and related academic publications. IES considered it essential to make this unpublished primary scientific data open to the public as soon as it was available, due to the international extent of Eyjafjallajökull's impacts (Porkelsson 2012).

In addition to sharing information via their websites and through frequent meetings, IMO, IES and other institutions, e.g. DCPEM, ISAVIA, the Environmental Agency, Health Authorities, and ministries and embassies, communicated with external agencies and institutes via informal means such as phone conversations and emails (Porkelsson 2012).

Based on the joint daily reports from IMO and IES, the NCCC media team produced daily (and sometimes multiple daily) reports in Icelandic and English on the eruption and conditions across the nation (Porkelsson 2012). The first daily report was disseminated on 14 April 2010, with a standardised form of the joint reports adopted some days later, and continuing every 
day during the summit eruption, after which the less frequently issued reports continued until 9 December 2010 (see http://www.sst.is/displayer. asp?cat_id=413).

In addition to posting on the DCPEM website, the reports were disseminated to government cabinets and ministries, foreign embassies located in Iceland, NGOs including the tourism sector and the Icelandic Red Cross, and media (Porkelsson 2012). As well as detailing the physical status of the eruption, the reports included impacts on the local environment, impacts on the Icelandic population, response measures being implemented and recommendations for effected populations to consider. These reports were openly discussed with local residents at a Temporary Service Centre established in Heimaland to deal with the crisis, which is in close proximity to Eyjafjallajökull. Residents were encouraged to drop into the Heimaland Temporary Service Centre to attend meetings, ask for information or be provided a meal.

Some survey respondents and interviewees reported that these services were very helpful and trustworthy, while others who did not attend any meetings believed they had missed out on accessing some critical information. A branch of the Temporary Service Centre was later established in Vík in Mýrdal for the population east of the eruption since the main centre in Heimaland was too far for many residents to travel, especially in relation to the ongoing ash fall and resuspension. The DCPEM in conjunction with IMO and IES held meetings critical to local residents in Vík, as well as Heimaland, where concerned citizens were given the opportunity to discuss their worries associated with increasing activity.

Despite the plans and strategies that had been developed to deal with volcanic crises in Iceland, all agencies and organisations involved in disaster risk reduction were faced with an event that they had not previously experienced. Ad hoc procedures were therefore added to the processes already in place in order to deal with unanticipated events as they occurred. One resident stated "[The regional police chief] has done some very good work in trying to make better plans with the residents." Part of the developing plans included detailed site visits and close collaborations with the tourism industry.

In consideration of the impact the continuing eruption was having on the tourism industry, a special response team was established. Led by the Ministry of Industry and Tourism (now the Ministry of the Interior), this team met every morning during the eruption, and included people from the DCPEM, IMO, IES, tourism operators, airlines and public relations people from the ministries and municipalities. This group played an active role in crisis communication with the responsibility of disseminating information to tourists stranded in Iceland and offering alternative activities to them while they were waiting for flights out of the country.

The role of this group continued well after the eruption was over, with responsibility shifting from crisis communication to the promotion of Iceland through an advertisement campaign entitled 'Inspired by Iceland' in an effort to attract tourists back in the wake of the Eyjafjallajökull eruption. The special response team has also been active during other volcanic crises such as the 2011 Grímsvötn and 2014-15 Bárðarbunga-Holuhraun eruptions.

\subsection{Impact on Local Residents}

While the evacuation was effective in preventing loss of life and serious injury due to jökulhlaup, there were no immediate plans in place with respect to mitigating the impacts of ash (Bird and Gísladóttir 2012; Heiðarsson et al. 2014). And of all the various volcanogenic hazards impacting local communities, survey respondents and interviewees declared the ash caused the greatest concern. A considerable amount of ash was ejected during the eruption, with large amounts deposited and resuspended causing high levels of localised pollution (Gudmundsson et al. 2012; Thorsteinsson et al. 2012). Many survey respondents and interviewees commented on the resuspended ash, with one stating: 
The impacts of the eruption are significant on my farm and at my neighbouring farms. It is very misleading and wrong description that the impacts were confined to Eyjafjöll...We still live with ash storm when the wind is blowing.

Air quality in Iceland, measured against the most commonly used health limit, was exceeded by orders of magnitude in local farming communities and villages during and after the Eyjafjallajökull eruption (Thorsteinsson et al. 2012). The health concerns among local residents (Bird and Gísladóttir 2012) were therefore justified, with resuspended ash proving to be of equal importance to that emitted from the volcano (Thorsteinsson et al. 2012). A study conducted by Carlsen et al. (2012) revealed that residents living in affected communities presented a highly increased prevalence of physical health conditions including tightness in the chest, coughing, phlegm, eye irritations and other respiratory problems.

Gissurardóttir (2015) found that residents with direct experience of and exposure to the Eyjafjallajökull eruption were also at greater risk of psychological morbidity in relation to mental distress and post-traumatic stress disorder. Survey respondents and interviewees noted the ongoing psychological impacts of the eruption and lack of crisis communication regarding health issues:

The ash seems to impact people a lot. They get claustrophobic and become confused and many are not able to make logical decisions.

The individual authorities' approach, such as those concerning health of residents, is reprehensible. Not enough consultation. No understanding on the psychological state of people [who were living under] ash fall and later ash storms for months. During the eruption, the area should have been evacuated - because it was sometimes uninhabitable there - but all tried to survive - many in a state of shock.

Supporting these comments, Gissurardóttir (2015) revealed the following factors as causes of psychological distress:

- Damage to personal property

- Feelings of insecurity during the eruption
- Being required to use protective equipment when working outside during the eruption

- Spending time outdoors in ash fall during the eruption due to work commitments or other duties

- Living in view of the eruption site

The impacted region was, and still is, an important agricultural region, with $15 \%$ of all cattle, $6 \%$ of all sheep, $17 \%$ of all horses and $12 \%$ of all dairy production in Iceland in 2010 (Farmers Association of Iceland 2010). Considering that animals are at a great risk of short and long-term mortality when they inhale or ingest fine ash particles (Lebon 2009; Wilson 2009; Wilson et al. 2011), it was understandable that the agricultural industry (Farmers Association of Iceland 2010) and local residents were gravely concerned about the health and wellbeing of their livestock (Bird and Gísladóttir 2012). Moreover, survey interviewees revealed that post-eruptive lahars and debris-flows also caused significant concern to farmers living south of the crater, where sediments were destroying infrastructure and agricultural land.

Thus, accurate, detailed and timely crisis communication was imperative in the lead up to and during the ongoing eruption, not only in relation to jökulhlaup risk but also covering the broad spectrum of impacts and well into the recovery phase.

\subsection{Demand for Accurate and Timely Information}

The demand for information during the Eyjafjallajökull eruption was unprecedented in Iceland, with communication and media relations suddenly evolving into a major component of the crisis operation (Guðmundsdóttir 2016). Without a doubt, the Eyjafjallajökull eruption dominated international media with the closure of transatlantic and European airspace causing tens of thousands of flights to be cancelled (Harris et al. 2012).

At the local level, the survey data shows that residents were actively using the IMO (Fig. 4) 


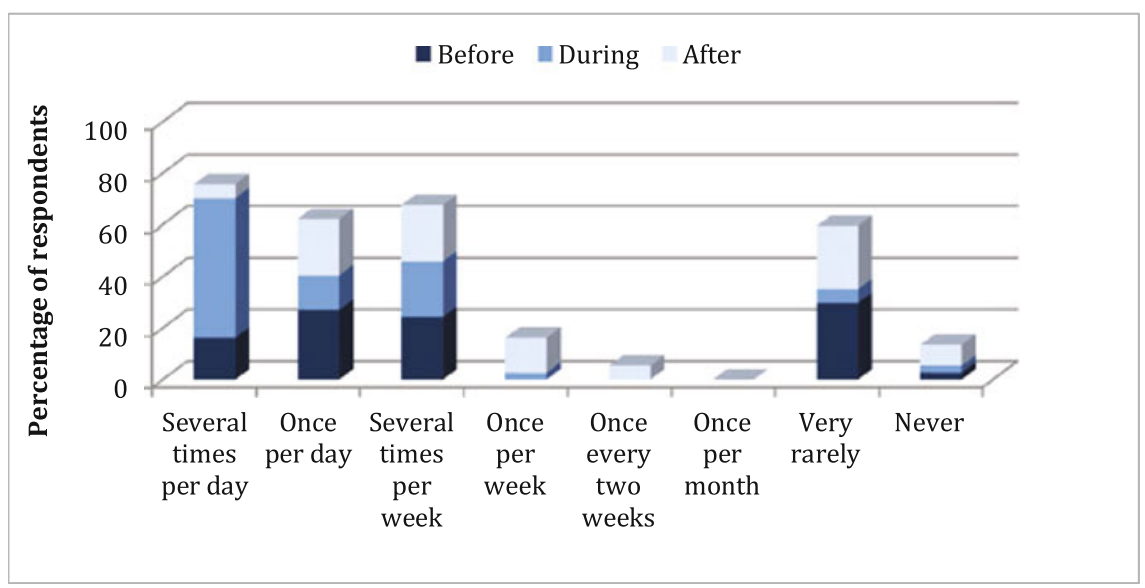

Fig. 4 Respondents' use of the IMO website before, during and after the 2010 Eyjafjallajökull eruptions

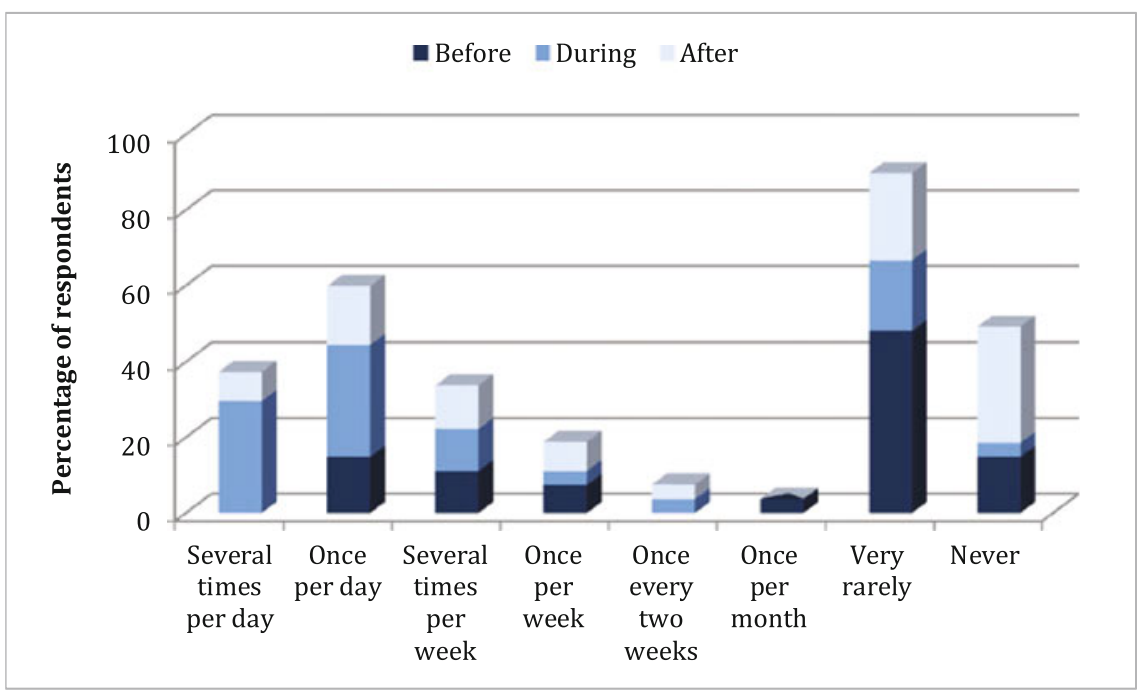

Fig. 5 Respondents' use of the DCPEM website before, during and after the 2010 Eyjafjallajökull eruptions

and DCPEM (Fig. 5) websites up to several times per day during the Eyjafjallajökull eruption. The IES website, which was mostly in English but not streaming real-time data, was not used as actively by survey respondents (Fig. 6); however, it was considered a valuable resource at an international level. In the initial stages, these agencies were not prepared to meet this demand (Heiðarsson et al. 2014).

As Porkelsson (2012) points out, IMO did not and still does not have a designated press office that can deal with a huge demand for crisis information yet they were faced with an enormous influx of requests, fielding calls from around 100 international reporters on just day two of the summit eruption. IES and DCPEM designated around 5-7 fulltime staff to work exclusively on dealing with the demand from international media (Porkelsson 2012).

Due to the demand for information, two media centres were opened under the supervision of DCPEM - one at NCCC in Reykjavík and a 


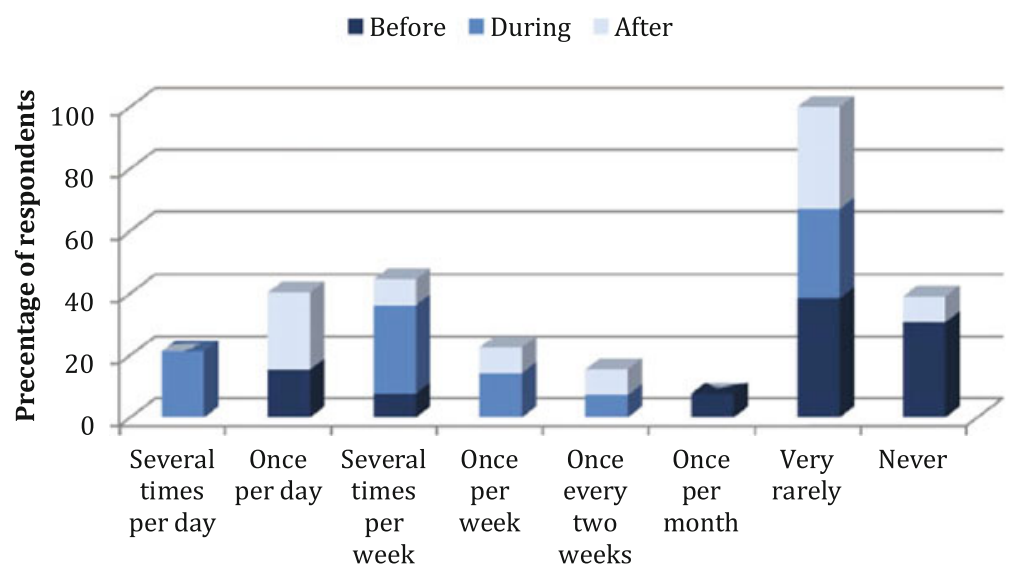

Fig. 6 Respondents' use of the IES website before, during and after the 2010 Eyjafjallajökull eruptions

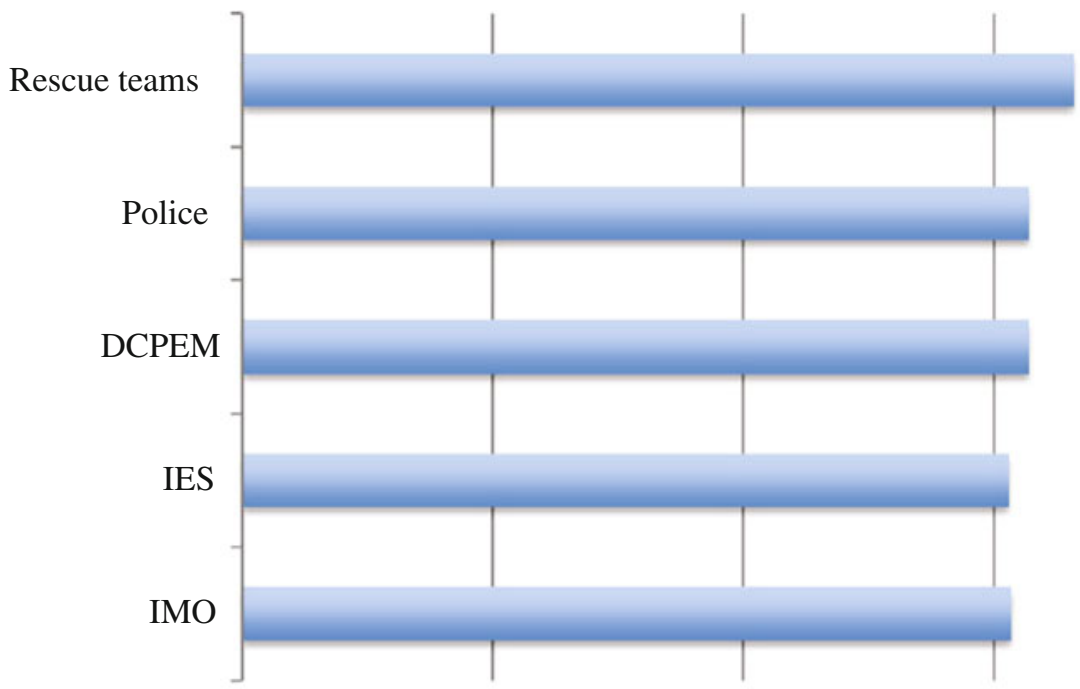

Strongly disagree

Strongly agree

Fig. 7 Respondents views towards the statements 'information released by IMO/IES/DCPEM/police/rescue teams is reliable'

Local Crisis Coordination Centre in Hvolsvöllur (Porkelsson 2012), which is the closest township to Eyjafjallajökull. With an overall aim to provide information with 'one voice', the teams based at each centre consisted of experts from DCPEM, ISAVIA, the Icelandic Coast Guard, Red Cross, the Icelandic Transport Authority, the
Icelandic Ministry for the Environment (currently entitled the Icelandic Ministry for the Environment and Natural Resources), the Icelandic Road and Coastal Administration, ICE-SAR and others. Overall, survey respondents agreed that the information provided by the various agencies was reliable (Fig. 7). 
Press conferences were held at both locations to help deal with the enormous interest in the event (Guðmundsdóttir 2016). In addition to distributing status reports, IMO and IES scientists were interviewed about facts and predictions of the continuing eruption, taking valuable time away from research and monitoring. Guðmundsdóttir (2016) reports, however, that many recognised this as an important part of their role as a scientist because media personnel will always be at the heart of the action and if an expert is not available for interview the media will seek information from anyone who is available and willing.

The National Broadcasting Service, 'RÚV' established a crisis-broadcasting studio in the NCCC media centre in Reykjavik enabling them to provide vital information to the Icelandic population (Heiðarsson et al. 2015). Other local news media, such as the 'Fréttablaðið' and 'Morgunblaðið' newspapers and the English newspaper 'The Reykjavik Grapevine' and magazine 'Iceland Review' also broadcasted news of the event via their traditional and online platforms.

Overall, the survey data suggests that residents' more frequently turned to the various media platforms for information (Fig. 8) with television, radio and Internet as the preferred platforms, respectively. However, some respondents also indicated that they accessed information from newspapers, books and information brochures. Once again, increased usage occurred during the eruption with many respondents accessing media sources several times per day (Fig. 9).

Even though survey respondents and interviewees indicated they trusted information from RÚV, they were overall critical of the media during the 2010 eruptions. When local residents were evacuated on 20 March 2010, the media were permitted to access and report from the evacuation zone. This incensed many survey respondents housed in the evacuation centres, where they watched live broadcasts from their evacuated farms, and in some instances, they hadn't had time to lock their front doors. One survey interviewee summed up many people's sentiment with the statement:

Scientists and media people receive a pass to go into the risk area on their own responsibility. Why are they allowed to go into the risk area when others are not?

Survey interviewees also found it disturbing when the international media portrayed them as helpless victims, dramatizing the summit eruption without any consideration of how people were living their day-to-day lives through the event. For impact, the media sought farmers who were in a state of shock at the realisation of the destructiveness of the heavy ash fall and this angered neighbouring residents.

Fig. 8 Respondents usage of various sources for hazard information

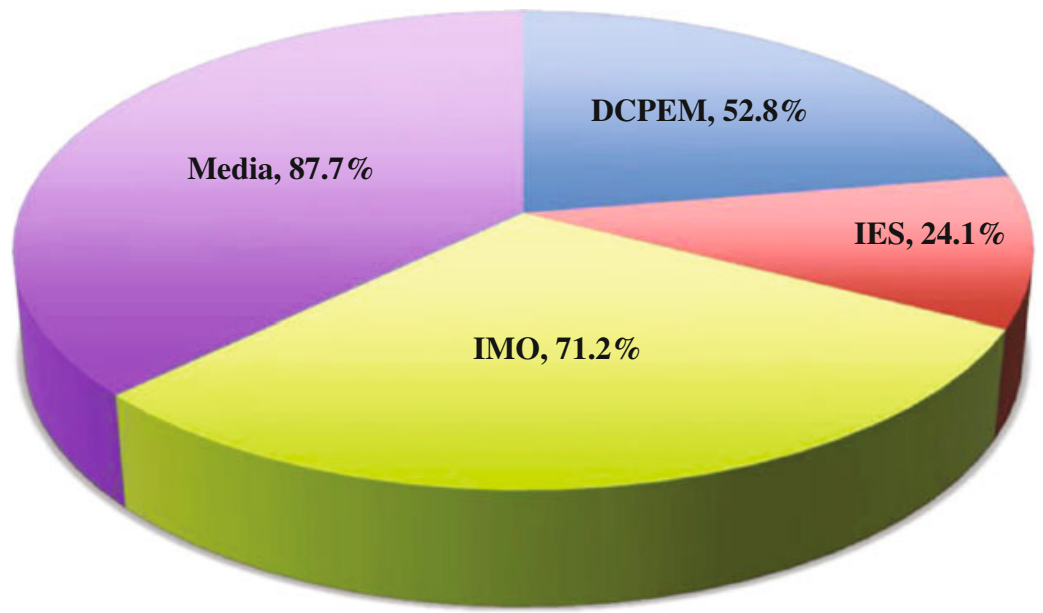




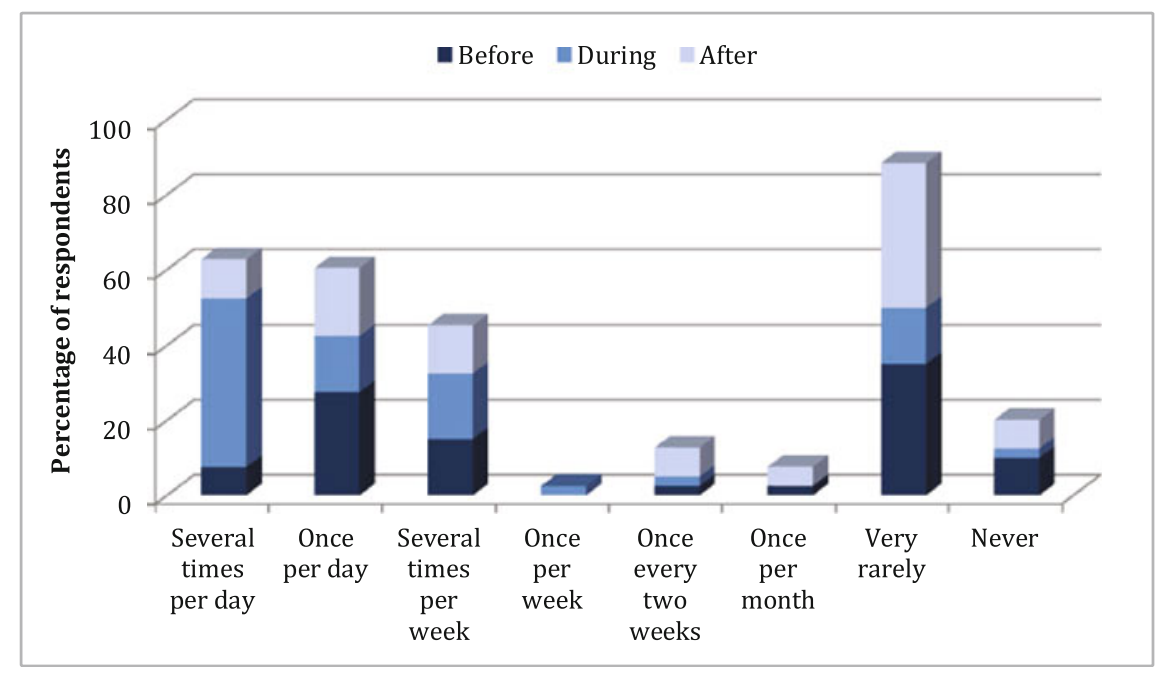

Fig. 9 Respondents' use of media before, during and after the 2010 Eyjafjallajökull eruption

I also found that the media exaggerated when they were broadcasting news from the area. They described it as such that everything here was covered in ash, and the situation in the area disastrous, but it was absolutely not so. A bit "overdramatizing" if I use slang. And we heard about farmers that were tired of the continuous pressure from the media.

[The media] said that the situation was more severe than it was. The situation was worse in a specific area but not elsewhere. And sometimes the news was erroneous. Media people were too aggressive to the residents, soon after the eruption started.

Residents were also frustrated with the media stating that the Eyjafjallajökull eruptions were "a show and nothing in comparison to what Katla can do". Residents living in close proximity are well aware of the potential hazards from a Katla eruption. However, this was the last thing they wanted to be reminded of while being impacted by ash fall, lightning, lahars and heavy sound blasts from Eyjafjallajökull's summit eruption (Bird and Gísladóttir 2012). To the detriment of the overall aim of DCPEM, IMO and IES to provide 'one voice', Iceland's president publicly stated: "you ain't seen nothing yet" in relation to a Katla eruption (see http://news.bbc.co.uk/2/hi/ programmes/newsnight/8631343.stm).

\section{Beyond Eyjafjallajökull 2010_Lessons Learnt and Improvements Made in an Unpredictable, Multi-hazard Environment}

The enormous workload generated by the Eyjafjallajökull eruptions cannot be denied. Considering Iceland's limited size in terms of manpower and resources, these events placed tremendous pressure on all those working in volcanic crisis management (Guðmundsdóttir 2016; Porkelsson 2012). Nevertheless, officials and scientists involved in the response made some great achievements under the circumstances, including:

- Pre-eruption risk communication, in particular at the town hall meetings, enabled trust to develop between emergency management officials and the general public, which increased the effectiveness of communication during the crisis.

- Timely evacuation advice and pre-existing trust led to the smooth evacuation of vulnerable populations during the summit eruption. 
- Ad hoc modifications to the IMO, IES and DCPEM websites enhanced the availability of information to key stakeholders including the public.

- Good collaborations were maintained with external partners based on already established communication links.

- Establishment of a crisis information centre enabled local residents to access more detailed information and support.

- Establishment of two media centres, with one being in close proximity to the eruption site, met the enormous demands from local and international media and thus relieved pressure on agencies and institutes involved in the response.

- IMO and IES increased the dissemination of primary scientific data on the physical status of the eruption to meet the growing demand.

However, not all of these initiatives worked well for all those involved. While it was considered essential that unpublished primary scientific data was publicly open and accessible for operational use, some foreign researchers viewed this an as opportunity to use the data for their own research agendas and publications (Porkelsson 2012).

Furthermore, there was some criticism regarding the fact that before the 2010 events, response plans were only in place for jökulhlaup risk while other volcanogenic hazards had not been addressed accordingly (Bird and Gísladóttir 2012). During the eruption, residents were calling for more information about the ash impacts and what these meant to human and animal health in addition to advice on how to mitigate the adverse affects. The need to adopt an all-hazards approach was again apparent during the 2014-15 Bárðarbunga-Holuhraun eruption when poisonous gases were the main cause of health concerns. Since the 2014-15 Bárðarbunga-Holuhraun eruption, NCIP and DCPEM for south Iceland are engaging with local communities in the development of all-hazards crisis management plans. Such engagement invites opportunities to enhance collaboration and communication prior to unrealised events occurring.
Despite these efforts to improve communications and instil learnings internally and externally with key stakeholders (Heiðarsson et al. 2015), more work is needed at the local and national level. For example, as formal guidelines for volcanic crisis communication were not in place prior to March 2010, officials were forced to develop ad hoc strategies during the Eyjafjallajökull eruption. Despite this experience, formal guidelines have not been established.

However, Guðmundsdóttir (2016) postulates a tentative guideline for best practice volcanic crisis communication based on officials' perspectives of the 2010 Eyjafjallajökull, 2011 Grímsvötn and 2014-15 Bárðarbunga-Holuhraun eruptions. These are:

1. Integrating communication into the management process

2. Cooperating at an institutional level

3. Coordinating messages

4. Providing truthful, honest and transparent information

5. Communicating in a proactive way

6. Being accessible and having a good relationship with the media

7. Understanding, informing and cooperating with the audience

8. Improvising if necessary

9. Planning, preparing, documenting the crisis communication

A key underlying theme here is that all officials worked together through mutual respect and understanding, so as to provide crisis communication via 'one voice'. To achieve this, Donovan and Oppenheimer (2012) highlight the importance of building and maintaining relationships well before a volcanic crisis ensues. The hazard and risk assessments, development of response plans and engagement of locals in these efforts in the years prior to the 2010 eruption are an excellent example of that approach.

Heiðarsson et al. (2014) also highlights the importance of the science sector providing clear and consistent messaging that is backed up by all government and non-government stakeholders. This is one of many key lessons that have been 
documented and investigated through the FUTUREVOLC project. FUTUREVOLC (http:// futurevolc.hi.is/), financed by the European Union's Seventh Programme for Research, Technological Development and Demonstration under grant agreement No 308377, was established following the Eyjafjallajökull eruption and has continued while other events and volcanic crises have taken place, e.g. seismic unrest in Bárðarbunga throughout 2014 and the 2014-15 Bárðarbunga-Holuhraun eruption (Heiðarsson et al. 2015).

After the Eyjafjallajökull eruption, IMO and IES began collaborating on a catalogue of Icelandic volcanoes, financed by ICAO. The work was then linked to the FUTUREVOLC project. The aim was to gather all the information electronically in an online catalogue, now available at (http://icelandicvolcanoes.is/), to improve public and official understanding of the current state of Iceland's volcanoes. The catalogue provides descriptions of the geological and tectonic setting of each volcano along with eruption history, characteristics and associated hazards, activity status, monitoring, and possible eruption scenarios. The catalogue has a strong emphasis on ash hazards and impacts, as it is designed with the needs of aviation for rapid information at times of potential crises. It is therefore not comprehensive when it comes to other hazards; e.g. information on flood hazards or air pollution is not extensive, and at present it does not contain information on response or disaster risk reduction plans. The catalogue is written in English, somewhat reducing its potential usefulness for local populations. The aim, however, is to develop an Icelandic version and to include all information and results from the ongoing long-term volcanic risk assessment program for Iceland.

While local residents are, in general, aware of the risks and emergency response procedures associated with a volcanic eruption in southern Iceland (Bird et al. 2009, 2011; Jóhannesdóttir 2005; Jóhannesdóttir and Gísladóttir 2010), tourists are not (Bird et al. 2010; Bird and Gísladóttir 2014). Although volcanic risk awareness among tourists appeared heightened during the Eyjafjallajökull eruption, it did not result in them seeking more information on safety strategies (Lund et al. 2010).

Since the Eyjafjallajökull eruption, tourism has rapidly grown in all regions across Iceland. Tourism currently accounts for more foreign exchange income than any other industry in Iceland, with employment in tourism-related industries increasing more than in any other sector of the economy (Óladóttir 2015). This growth is expected to continue in the coming years.

Increased tourism, however, ultimately leads to increases in the number of tourists exposed to risks associated with volcanic eruptions. Initiatives like the Catalogue of Icelandic Volcanoes and the introduction of real-time alerts in English using social media and text messaging are aimed at enhancing awareness among international visitors to Iceland (Heiðarsson et al. 2015). However, there is currently little evidence as to whether or not these initiatives are successfully inciting risk reduction behaviours.

The experience gained from the Eyjafjallajökull eruption is important and the immediate crisis communication strategies were effective in promoting the successful evacuation of local residents. However, the ash fall problems illustrated the need for necessary precautions and broadly defined preparedness strategies in order to increase the resilience of affected communities. This need for resilience is not confined to the local population, but also includes the ever-increasing number of tourists who visit Iceland and who engage in activities around Iceland's active volcanoes.

Acknowledgements All interviewees and respondents are graciously thanked for their willingness to participate in the survey. Contributions from the Ash Fall Impacts Working Group, Katharine Haynes, Carolina Garcia Londoño and Guðrún Pétursdóttir are appreciated in relation to the development of the questionnaire. The two anonymous reviewers are also thanked for providing invaluable recommendations that helped improve the manuscript from the original. The preparation of this paper has been supported by the Nordic Centre of Excellence for Resilience and Societal Security-NORDRESS, which is funded by the Nordic Societal Security Programme. Pórdís Högnadóttir helped with the preparation of Fig. 1 and Ísólfur Gylfi Pálmason prepared population data for Rangárping eystra. 


\section{References}

Almannavarnir (2016a) Civil protection in Iceland. http://www.almannavarnir.is/english/about-the-depart ment-of-civil-protection-and-emergency-management/. Accessed 8 Nov 2016

Almannavarnir (2016b) Emergency response. http://www. almannavarnir.is/english/general-information/emergencyresponse/. Accessed 8 Nov 2016

Bennett AJ, Odams P, Edwards D, Arason P (2010) Monitoring of lightning from the April-May 2010 Eyjafjallajökull volcanic eruption using a very low frequency lightning location network. Environ Res Lett 5:044013

Bird D, Gísladóttir G (2012) Residents' attitudes and behaviour before and after the 2010 Eyjafjallajökull eruptions - a case study from southern Iceland. Bull Volcanol 74:1263-1279

Bird D, Gísladóttir G (2014) Southern Iceland—volcanoes, tourism and volcanic risk reduction. In: Erfurt-Cooper P (ed) Volcanic tourist destinations. Springer, Geoheritage, Geoparks and Geotourism, pp 35-46

Bird DK, Gísladóttir G, Dominey-Howes D (2009) Resident perception of volcanic hazards and evacuation procedures. Nat Hazards Earth Syst Sci 9:251-266

Bird DK, Gísladóttir G, Dominey-Howes D (2010) Volcanic risk and tourism in southern Iceland: implications for hazard, risk and emergency response education and training. J Volcanol Geoth Res 189:33-48

Bird DK, Gísladóttir G, Dominey-Howes D (2011) Different communities, different perspectives: issues affecting residents' response to a volcanic eruption in southern Iceland. Bull Volcanol 73:1209-1227

Carlsen HK, Hauksdottir A, Valdimarsdottir UA, Gíslason T, Einarsdottir G, Runolfsson $\mathrm{H}$, Briem $\mathrm{H}$, Finnbjornsdottir RG, Gudmundsson S, Kolbeinsson TB, Thorsteinsson T, Pétursdóttir G (2012) Health effects following the Eyjafjallajökull volcanic eruption: a cohort study. BMJ Open 2

Donovan A, Oppenheimer C (2012) Governing the lithosphere: insights from Eyjafjallajökull concerning the role of scientists in supporting decision-making on active volcanoes. J Geophys Res 117:B03214

Donovan AR, Oppenheimer C (2010) Commentary: the 2010 Eyjafjallajökull eruption and the reconstruction of geography. Geogr J. doi:10.1111/j.1475-4959. 2010.00379.x

Farmers Association of Iceland (2010) 19 April 2010 announcement from the Farmers Association of Iceland - the volcanic eruption in Iceland and its effects on Icelandic agriculture, Bændasamtök Íslands. http:// www.bondi.is/lisalib/getfile.aspx?itemid=2747.

Accessed 19 June 2011

Gislason SR, Hassenkam T, Nedel S, Bovet N, Eiriksdottir ES, Alfredsson HA, Hem CP, Balogh ZI, Dideriksen K, Oskarsson N, Sigfusson B, Larsen G, Stipp SLS (2011) Characterization of Eyjafjallajökull volcanic ash particles and a protocol for rapid risk assessment. Proc Natl Acad Sci U S A 108:7307-7312
Gissurardóttir ÓS (2015) Mental health following the volcanic eruption in Eyjafjallajökull volcano in Iceland in 2010: a population-based study. Master of Public Health Sciences, Centre of Public Health, School of Health Sciences, University of Iceland. Reykjavík, p 45

Guðmundsdóttir BN (2016) Best practices in Icelandic crisis communication during volcanic eruptions: development of a tentative framework. Masters thesis in Environment and Natural Resources, Faculty of Life and Environmental Sciences, School of Engineering and Natural Sciences, University of Iceland. Reykjavik, p 65

Gudmundsson MT, Pedersen R, Vogfjörd K, Thorbjarnardóttir B, Jakobsdóttir S, Roberts MJ (2010) Eruptions of Eyjafjallajökull volcano, Iceland. EOS Trans AGU 91:190-191

Gudmundsson MT, Thordarson T, Höskuldsson Á, Larsen G, Björnsson H, Prata FJ, Oddsson B, Magnússon E, Högnadóttir T, Petersen GN, Hayward CL, Stevenson JA, Jónsdóttir I (2012) Ash generation and distribution from the April-May 2010 eruption of Eyjafjallajökull, Iceland. Sci, Rep, p 2

Guðmundsson MT, Gylfason ÁG (2005) Hættumat vegna eldgosa og hlaupa frá vestanverðum Mýrdalsjökli og Eyjafjallajökli. Ríkislögreglustjórinn and Háskólaútgáfan, Reykjavík, p 210

Guðmundsson MT, Elíasson J, Larsen G, Gylfason ÁG, Einarsson P, Jóhanesson T, Hákonardóttir KM, Torfason H (2005) Yfirlit um hættu vegna eldgosa og hlaupa frá vesturhluta Mýrdalsjökuls og Eyjafjallajökli. In: Guðmundsson MT, Gylfason ÁG (eds) Hættumat vegna eldgosa og hlaupa frá vestanverðum Mýrdalsjökli og Eyjafjallajökli. Ríkislögreglustjórinn and Háskólaútgáfan, Reykjavík, pp 11-44

Harris AJL, Gurioli L, Hughes EE, Lagreulet S (2012) Impact of the Eyjafjallajökull ash cloud: a newspaper perspective. J Geophys Res 117:B00C08

Heiðarsson EP, Loughlin SC, Witham C, Barsotti S (2014) Report on forensic analysis of the Eyjafjallajökull and Grímsvötn communication and risk management response across Europe. European volcanological supersite in Iceland: a monitoring system and network for the future. FutureVolc, Reykjavík, p 198

Heiðarsson EP, Loughlin SC, Witham C, Barsotti S (2015) D3.2 - Information for EU-MIC and scenarios for major events. European volcanological supersite in Iceland: a monitoring system and network for the future. FutureVolc, Reykjavík, p 72

Jensen EH, Helgason JK, Einarsson S, Sverrisdottir G, Höskuldsson A, Oddsson B (2013) Lahar, floods and debris flows resulting from the 2010 eruption of Eyjafjallajökull: observations, mapping, and modelling. In: Margottini C, Canuti P, Sassa K (eds) Landslide science and practice, vol 3., Spatial analysis and modellingSpringer, Berlin, Heidelberg, pp 435-440

Johannesdottir G (2016) National risk assessment for Iceland. Executive summary. Department of Civil Protection and Emergency Management, National Commissioner of the Icelandic Police, Reykjavík, p 22 
Jóhannesdóttir G, Gísladóttir G (2010) People living under threat of volcanic hazard in southern Iceland: vulnerability and risk perception. Nat Hazards Earth Syst Sci 10:407-420

Jóhannesdóttir G (2005) Við tölum aldrei um Kötlu hér mat íbúa á hættu vegna Kötlugoss. Department of Geology and Geography, University of Iceland, Reykjavík, p 103

Karlsdóttir S, Petersen GN, Björnsson H, Pétursson H, Porsteinsson H, Arason P (2010) Eyjafjallajökull eruption 2010 - the role of IMO. http://en.vedur.is/ earthquakes-and-volcanism/articles/nr/2072. Accessed 17 July 2016

Larsen G, Dugmore A, Newton A (1999) Geochemistry of historical-age silicic tephras in Iceland. Holocene 9:463-471

Lebon SLG (2009) Volcanic activity and environment: Impacts on agriculture and use of geological data to improve recovery processes. Faculty of Earth Sciences, Masters Thesis in Environmental Sciences and Natural Resources Management, Earth Science Institute, University of Iceland, Reykjavik, ISBN 978-9979-9914-0-3

Lund KA, Benediktsson K, Mustonen TA (2010) The Eyjafjallajökull eruption and tourism: report from a survey in 2010. Icelandic Tourism Research Centre, Reykjavík, p 23

Ministry of the Interior (2008) Civil protection Act No. 82, 12 June 2008. https://eng.innanrikisraduneyti. is/laws-and-regulations/english/civil-protection/. Accessed 22 Sept 2016

Óladóttir OP (2015) Tourism in Iceland in figures. Ferðamálastofa, Reykjavík, p 27

Sigmundsson F, Hreinsdóttir S, Hooper A, Árnadóttir T, Pedersen R, Roberts MJ, Óskarsson N, Auriac A, Decriem J, Einarsson P, Geirsson H, Hensch M, Ófeigsson BG, Sturkell E, Sveinbjörnsson H, Feigl KL (2010) Intrusion triggering of the 2010 Eyjafjallajökull explosive eruption. Nature 468:426-432

Open Access This chapter is licensed under the terms of the Creative Commons Attribution 4.0 International License (http://creativecommons.org/licenses/by/4.0/), which permits use, sharing, adaptation, distribution and reproduction in any medium or format, as long as you give appropriate credit to the original author(s) and the source, provide a link to the Creative Commons license and indicate if changes were made.
Sigurðsson O, Sigurðsson G, Björnsson BB, Pagneux EP, Zóphóníasson S, Einarsson B, Pórarinsson Ó, Jóhannesson T (2011) Flood warning system and jökulhlaups-Eyjafjallajökull, Icelandic Meteorlogical Office. http://en.vedur.is/hydrology/articles/nr/2097. Accessed 23 June 2011

Thorsteinsson T, Jóhannsson T, Stohl A, Kristiansen NI (2012) High levels of particulate matter in Iceland due to direct ash emissions by the Eyjafjallajökull eruption and resuspension of deposited ash. J Geophys Res Solid Earth 117

Veðurstofa Íslands (2010) Update on activity: eruption in Eyjafjallajökull, Iceland. http://en.vedur.is/earthquakesand-volcanism/articles/nr/1884. Accessed 13 July 2011

Vogfjörd KS, Jakobsdóttir SS, Guðmundsson GB, Roberts MJ, Ágústsson K, Arason T, Geirsson H, Karlsdóttir S, Hjaltadóttir S, Ólafsdóttir U, Thorbjarnardóttir B, Skaftadóttir T, Sturkell E, Jónasdóttir EB, Hafsteinsson G, Sveinbjörnsson H, Stefánsson R, Jónsson TV (2005) Forecasting and monitoring a subglacial eruption in Iceland. EOS Trans Am Geophys Union 86:245-252

Wilson T, Cole J, Stewart C, Cronin S, Johnston D (2011) Ash storms: impacts of wind-remobilised volcanic ash on rural communities and agriculture following the 1991 Hudson eruption, southern Patagonia, Chile. Bull Volcanol 73:223-239

Wilson TM (2009) Vulnerability of pastoral farming systems to volcanic ashfall hazards. Doctor of Philosophy in Hazard and Disaster Management, Natural Hazards Research Centre, Department of Geological Sciences, University of Canterbury, Christchurch, p 241

Porkelsson B (2012) The 2010 Eyjafjallajökull eruption, Iceland. Report to ICAO-June 2012. Icelandic Meteorological Office; Institute of Earth Sciences, University of Iceland; The National Commissioner of the Icelandic Police, Reykjavik, p 206

The images or other third party material in this chapter are included in the chapter's Creative Commons license, unless indicated otherwise in a credit line to the material. If material is not included in the chapter's Creative Commons license and your intended use is not permitted by statutory regulation or exceeds the permitted use, you will need to obtain permission directly from the copyright holder. 